\title{
Research on the Logic, Dilemma and Strategy of Undertaking Industrial Transfer in Underdeveloped Areas
}

\author{
Qin Wu, Xingyuan Wang \\ School of Business, Nanjing Normal University, Nanjing, China \\ Email: wuqin572020@163.com
}

How to cite this paper: $\mathrm{Wu}, \mathrm{Q}$. and Wang, X.Y. (2019) Research on the Logic, Dilemma and Strategy of Undertaking Industrial Transfer in Underdeveloped Areas. Open Journal of Social Sciences, 7, 86-94. https://doi.org/10.4236/jss.2019.712007

Received: November 15, 2019

Accepted: December 3, 2019

Published: December 6, 2019

Copyright $\odot 2019$ by author(s) and Scientific Research Publishing Inc. This work is licensed under the Creative Commons Attribution International License (CC BY 4.0).

http://creativecommons.org/licenses/by/4.0/

\begin{abstract}
The economically underdeveloped regions have improved the economic efficiency by accommodating industries in economically developed regions, and have absorbed the employment of residents. This is an important path for economic transformation in economically underdeveloped regions. In economically underdeveloped areas to undertake industrial transfer, it is necessary to give play to the advantages of resource endowment in backward regions. It is necessary to realize technology introduction through industrial undertaking, and it is necessary to accelerate the cultivation of local market entities. So as to truly utilize the resource advantages, technology advantages and talent advantages brought about by industrial transfer, which is the logic for undertaking economic transfer in economically underdeveloped regions. At present, in the process of undertaking industrial transfer in economically underdeveloped areas, there are some scientific difficulties such as lack of scientific programs to undertake industries, neglect of technology introduction in industrial transfer, and low participation of local market participants. Therefore, economically underdeveloped areas should combine regional resource endowments to formulate scientific industrial undertaking plans; at the same time, backward areas must strengthen the introduction of industrial technology, attach importance to the promotion of industry, schools, and research institutes; and the level of local participation encourages local companies to participate in the transfer of industries.
\end{abstract}

\section{Keywords}

Economically Underdeveloped Regions, Undertaking Industrial Transfer, Resource Endowment, Latecomer Advantage 


\section{Introduction}

In the theoretical analysis framework of regional economics and industrial economics, industrial transfer is an important economic phenomenon that occurs between regions with different levels of economic development. It refers to the compliance of some enterprises in developed regions under the conditions of market economy. The change of comparative advantage, through direct investment across regions, shifts the production of some industries to the developing regions, thus showing the phenomenon that the industry shifts from developed regions to developing regions in the spatial distribution of industries. Economically underdeveloped regions have improved the economic efficiency and absorbed the employment of residents by undertaking industries in economically developed regions. This is an important path for economic transformation in economically underdeveloped regions. At the same time, undertaking industrial transfer in economically developed regions is an important measure and effective attempt to respond to the challenges of economic structure optimization, economic growth, and economic transformation. Therefore, this paper analyzes the economic logic of undertaking industrial transfer in economically underdeveloped areas, and explores the difficulties of undertaking economic transfer in economically underdeveloped areas. On this basis, combined with the actual development of economically underdeveloped regions, the article proposes strategies for undertaking industrial transfer in economically underdeveloped regions [1].

\section{The Logic of Undertaking Industrial Transfer in Economically Underdeveloped Regions}

\subsection{Exploiting the Resource Endowment Advantage of Backward Regions and Realizing the Rapid Development of Regional National Economy}

Under developing regions in economically underdeveloped regions can effectively exploit the resource endowment advantages of backward regions and realize the rapid development of regional national economies. Generally speaking, the economic level of economically underdeveloped areas is low, and the employment level of residents is not high, but the labor resources are abundant and the income of residents is difficult to increase. With the immigration of external industries, the number of enterprises in economically underdeveloped areas has increased, the employment level of residents has increased, the production efficiency of the region has increased, and various economic factors have begun to gather, eventually achieving the rapid development of the regional national economy [2].

\subsection{Realizing the Introduction of Technology through Industrial Undertaking and Improving the Overall Efficiency of Regional Economic Activities}

Economically underdeveloped areas will adopt technology to achieve technology 
introduction and improve the overall efficiency of regional economic activities. For a long time, the technical level of economically underdeveloped areas is relatively low, so production efficiency and market competitiveness are relatively low. Through the introduction of industries, a large number of enterprises will bring new business ideas, production techniques and production technologies, which can improve the technical level of the region, and ultimately effectively improve the overall efficiency of regional economic activities, and promote various aspects of regional economy and human resources quality improvement.

\subsection{Industry Undertaking Can Cultivate Local Market Entities and Improve the Employment Level of Residents in Backward Areas}

Economically underdeveloped areas can foster local market entities through industrial undertakings and improve the employment level of residents in backward areas. Before the reform and opening up, due to the lack of job opportunities, the surplus of human resources in rural areas was difficult to exert. After the reform and opening up, a large number of rural laborers began to shift to cities, resulting in a large outflow of talents in economically underdeveloped areas. Develop the Matthew effect model that enters the "strong and strong". In order to break the Matthew effect of regional economic development, economically underdeveloped regions must cultivate local market players through industry, improve the employment level of residents in backward areas, and keep enterprises and talents in the local area, so as to achieve sustainable development of regional economy.

\section{The Economically Underdeveloped Areas to Undertake the Dilemma of Industrial Transfer}

Judging from the current economically underdeveloped areas to undertake industrial transfer, many regions have no scientific industrial undertakings in the process of undertaking industrial transfer, and do not pay attention to technology introduction in the process of industrial transfer, and local enterprises have low participation. The economic effects brought about by the transfer of the industry are not good. This section of the article analyzes this in detail [3].

\subsection{Lack of Scientific Programs to Undertake Industries, and Do Not Give Full Play to Regional Resource Endowment Advantages}

Judging from the current practice cases of undertaking industrial transfer in economically underdeveloped regions, most local governments have not formulated scientific plans to undertake industrial transfer, which makes contemporary industrial development planning unscientific and unreasonable, and the efficiency of undertaking industrial transfer is not high and difficult to continue. For economically underdeveloped regions, the lack of scientific programs to undertake industries will make it difficult to exploit the resource endowment ad- 
vantages of underdeveloped regions, thus failing to achieve economic leapfrog development.

First of all, economically underdeveloped areas often have better natural resources, and some economically underdeveloped areas have already formed local characteristic industries. Therefore, in the process of introducing industries, it is necessary to give priority to the introduction of industries that meet their own resource endowments, instead of undertaking any industry. It is necessary to realize the transformation and upgrading of local advantageous industries through industrial undertaking.

Secondly, the employment rate of residents in economically underdeveloped areas is relatively low. Therefore, it is very necessary to consider the introduction of labor-intensive enterprises. However, in the process of undertaking industrial transfer, the economically underdeveloped areas have not integrated the industries.

Moreover, the natural environment in economically underdeveloped areas tends to be better, so in the process of introducing industries, we must pay attention to the protection of the ecological environment. From the perspective of industrial development in economically developed regions, environmental governance in developed regions often goes through the process of "first pollution, then governance". Economically underdeveloped regions can take measures to avoid this dilemma, but at present, many economies are underdeveloped. The region attracts polluting industries by sacrificing the ecological environment.

\subsection{Ignoring the Introduction of Technology in Industrial Transfer, the Path of Industrial Development Is Not Scientific}

In the era of knowledge economy, science and technology are the primary productive forces. To achieve leap-forward development in economically underdeveloped regions, we must rely on the power of science and technology to enhance regional production efficiency and production levels, and ultimately improve the competitiveness of regional products in the market. From the perspective of industrial undertaking practices in economically underdeveloped regions, some economically underdeveloped regions neglect technology introduction in industrial transfer, and the path of industrial development is not scientific.

First, the industry does not pay attention to the introduction of advanced technology industries. In order to expand the scale of investment attraction, many economically underdeveloped regions do not assign priority standards to undertake industries. All industries that can be introduced are introduced, which leads to many backward industries and polluting industries. The entry of high-energy-consuming industries has had a negative impact on the local ecological environment and will also have a restrictive effect on the long-term development of local industries.

Second, local governments in economically underdeveloped regions have neglected the introduction of advanced technology industries, which has made the use of local investment resources unscientific and unreasonable, and has not 
optimized the use of their own resources. More importantly, due to the lack of high-tech industries, the talent structure in economically underdeveloped regions is not good, which is very unfavorable to the sustainable development of local economy, society, culture and science and technology [4].

Third, at the micro level, although the backward industries can absorb the employment of some residents, because the enterprises in backward industries lack sufficient market competitiveness, this will make the enterprises easy to be eliminated, thus making the regional economic development lack of stamina. It is difficult to sustain [5].

\subsection{The Participation of Local Market Participants Is Low, and the Employment of Local Residents Is Not Absorbed in the Process of Industrial Transfer}

In the process of undertaking industrial transfer in economically underdeveloped areas, cultivating local enterprises is an important goal. This will help to keep the various elements of economic development in the local area and truly promote the efficient, stable and sustainable development of the regional economy [6]. At present, economically underdeveloped regions have not guided local private enterprises to participate in industrial transfer in the process of undertaking transfer industries in developed regions [7].

On the one hand, the economically underdeveloped regions have not cultivated a number of local leading enterprises, which makes the market entities in economically underdeveloped regions do not have advantages in terms of scale, technology and talents, so it is difficult to effectively participate in the competition of industry undertaking. [8] However, once local enterprises do not participate in the industrial transfer of economically underdeveloped regions, local enterprises will miss the opportunity of development and fall into a vicious circle of development [1].

On the other hand, state-owned enterprises, private enterprises and township enterprises in economically underdeveloped areas urgently need to update technology, equipment and talents [9]. Undertaking industrial transfer is an important strategic opportunity for their transformation and development. However, the current market entities in economically underdeveloped regions have insufficient meaning in this respect, and local government's propaganda and guidance work has serious deficiencies [10].

\section{Strategies for Undertaking Industrial Transfer in Underdeveloped Regions}

\subsection{Combining the Resource Endowments of the Region to Formulate a Scientific Industrial Undertaking Plan}

Economically underdeveloped areas should combine regional resource endowments, formulate scientific industrial undertaking plans, and optimize the types of industries undertaken [11]. This is the primary strategy for undertaking economic transfer in economically underdeveloped areas. The specific measures to 
be taken include the following three aspects:

First, the governments of economically underdeveloped regions should determine the types of industries that should be developed in the region according to their local location advantages, resource advantages, technological advantages, human resources advantages and social and cultural advantages, and clarify the direction of industrial undertakings [12]. It can effectively improve the efficiency of industrial undertakings, and can effectively improve the utilization efficiency of investment-inviting resources in economically underdeveloped areas [13].

Second, the economically underdeveloped areas should combine the functional planning of their own cities and rationally arrange the industries they undertake to ensure that while exerting various regional advantages, they will drive urban development, facilitate residents' lives, and promote the deep integration of cities and industries. It is necessary to make full use of the opportunities undertaken by the industry to implement urban renewal and urban expansion, and to achieve efficient, stable and sustainable development of the national economy in economically underdeveloped areas [14].

Third, in the process of promoting industrial undertaking work, economically underdeveloped regions must adopt diversified means to attract external enterprises. They should adopt not only traditional investment promotion policies such as fiscal and tax subsidies, but also preferential policies for granting land, technical research and development support, and supporting facilities. Improve the preferential measures in other areas, give enterprises all-round services and promote regional economic development.

\subsection{Strengthening the Introduction of Industrial Technology and Attaching Importance to the Cooperation of Industry, Schools and Research Units}

In the process of undertaking industrial transfer in economically developed regions, economically underdeveloped regions should strengthen the introduction of industrial technology, especially the promotion of cooperation in production, learning and research. This is the optimization of economic structure and economic growth in economically underdeveloped regions. The important measures and effective attempts to gradually adjust and economically drive the overall transformation challenge include the following three aspects [15].

First of all, formulate industrial import measures for priority high-tech industries, give preferential measures to the financial industry, finance, taxation, land, supporting, employee medical care and education, attract high-tech enterprises and high-tech talents to settle in, and improve the economy of underdeveloped regions. The quality and sustainability of development.

Secondly, economically underdeveloped areas should pay attention to the cooperation of industry, schools and research units, and build a communication platform through the government to promote deep cooperation between enterprises in the industry and schools. On the one hand, accelerate the research results of research institutions such as universities and research institutes to be 
quickly transformed into practical applications of enterprises and promote economic development; on the other hand, accelerate the technological upgrading of enterprises in the market and enhance the competitiveness of enterprises in the market.

Furthermore, local governments should strengthen education and training support in the region, and strengthen the introduction of external scientific and technological talents, and implement policies that emphasize both internal and external talents. By taking advantage of the opportunities of industrial transfer, economically underdeveloped regions can create a new highland for comprehensive talent pooling.

\subsection{Enhancing the Participation of Local Enterprises and Encouraging Local Enterprises to Participate in Undertaking Industrial Transfer}

In the process of undertaking industrial transfer in economically developed regions, economically underdeveloped regions should increase the participation of local enterprises, encourage local enterprises to participate in undertaking industrial transfer, and thus cultivate a group of local leading enterprises, and ultimately enhance the vitality and tenacity of the local economy.

First, based on regional industrial development planning, foster a group of leading enterprises, guide local leading enterprises to participate in industrial undertakings, help local state-owned enterprises and private enterprises to achieve transformational development, improve the comprehensive strength of local enterprises, and enhance the local enterprises. The core competitiveness will truly improve the comprehensive development level of economically underdeveloped regions.

Second, in economically underdeveloped regions, the government can set up an industrial fund with the theme of industrial undertaking, invite local enterprises and investors to participate, and let local enterprises and residents share the regional economic development dividend. At the same time, local governments can encourage local enterprises to vigorously develop with external enterprises to achieve a win-win situation for both internal and external enterprises.

\section{Research Summary}

All in all, undertaking industrial transfer in economically developed regions is an important measure and effective attempt to respond to the challenges of economic structure optimization, economic growth, and economic transformation. To undertake industrial transfer in economically underdeveloped areas can achieve rapid development of regional national economy, improve the overall efficiency of regional economic activities, and improve the employment level of residents in backward areas. However, the current economically underdeveloped regions have not fully utilized the regional resource endowment advantages in the process of undertaking industrial transfer. At the same time, the path of in- 
dustrial development is not scientific, and the employment of local residents is not absorbed in the process of industrial transfer. These problems need to be improved. Therefore, economically underdeveloped areas should formulate scientific industrial undertaking plans. Local governments should promote cooperation between industries, schools and research units, and encourage local enterprises to participate in undertaking industrial transfer, and ultimately realize the rapid development of the national economy in economically underdeveloped areas.

\section{Conflicts of Interest}

The authors declare no conflicts of interest regarding the publication of this paper.

\section{References}

[1] Okubo, T. (2009) Trade Liberalisation and Agglomeration with Firm Heterogeneity: Forward and Backward Linkages. Regional Science and Urban Economics, 39, 530-541. https://doi.org/10.1016/j.regsciurbeco.2009.03.005

[2] Martin, P. and Ottaviano, G.I.P. (1999) Growing Locations: Industry Location in a Model of Endogenous Growth. European Economic Review, 43, 281-302. https://doi.org/10.1016/S0014-2921(98)00031-2

[3] Krugman, P. and Venables, A.J. (1996) Integration, Specialization, and Adjustment. European Economic Review, 40, 959-967. https://doi.org/10.1016/0014-2921(95)00104-2

[4] Head, K., Ries, J. and Swenson, D. (1995) Agglomeration Benefits and Location Choice: Evidence from Japanese Manufacturing Investments in the United States. Journal of International Economics, 38, 223-247. https://doi.org/10.1016/0022-1996(94)01351-R

[5] Blomström, M., Kokko, A. and Zejan, M. (1994) Host Country Competition, Labor Skills, and Technology Transfer by Multinationals. Review of World Economics, 130, 521-533. https://doi.org/10.1007/BF02707611

[6] Leigh, R. and North, D.J. (1978) Regional Aspects of Acquisition Activity in British Manufacturing Industry. Regional Studies, 12, 227-245. https://doi.org/10.1080/09595237800185191

[7] Subodh, K. and Russell, R.R. (2002) Technological Change, Technological Catch-Up and Capital Deepening: Relative Contributions to Growth and Convergence. The American Economist, 92, 527-548. https://doi.org/10.1257/00028280260136381

[8] Lan, P. (1996) Technology Transfer to China through Foreign Direct Investment.

[9] Weseloh, R.M., Nordlund, D.A., Jones, R.L. and Lewis, W.J. (1981) Host Location by Parasitoids. Semiochemicals: Their Role in Pest Control.

[10] Sturgeon, T.J. (2002) Modular Production Networks: A New American Model of Industrial Organization. Industrial and Corporate Change, 11, 451-496. https://doi.org/10.1093/icc/11.3.451

[11] Vernon, R. (1996) International Investment and International Trade in the Product Cycle. The Quarterly Journal of Economics, 2, 190-207. https://doi.org/10.2307/1880689

[12] Feser, E. and Bergman, E. (2000) National Industry Cluster Templates: A Frame- 
work for Applied Regional Cluster Analysis. Regional Studies, 34, 1-19. https://doi.org/10.1080/00343400050005844

[13] United Nations Industrial Development Organization (2002) Industrial Development Report 2002/2003: Competing through Innovation and Learning.

[14] Watts, H.D. (1980) The Large Industrial Enterprise.

[15] Akamatus, K. (1962) A Historical Pattern of Economic Growth in Developing Countries. The Developing Economies, 1, 3-25.

https://doi.org/10.1111/j.1746-1049.1962.tb01020.x 